\title{
Phyllophorus (Phyllophorus) maculatus, a new species of sea cucumber from the Yellow Sea (Echinodermata: Holothuroidea: Dendrochirotida)
}

\author{
YULIN LIAO ${ }^{1}$, DAVID L. PAWSON ${ }^{2} \&$ WEI LIU ${ }^{3}$ \\ ${ }^{1}$ Institute of Oceanology, Chinese Academy of Sciences, Qingdao 266071, China \\ ${ }^{2}$ National Museum of Natural History, Mail Stop MRC163, Smithsonian Institution, Washington DC 20013-7012 \\ ${ }^{3}$ Wei Fang Marine Environmental Monitoring Central Station of Shandong Province, Wei Fang 261041, China. \\ E-mail:pawsond@si.edu
}

\begin{abstract}
Phyllophorus (Phyllophorus) maculatus new species is described from a depth of 22-45 meters near the western edge of the Yellow Sea. The body is cylindrical, with body wall ossicles present only in the anal region. Ossicles are four-pillared tables with low spires and indented disc margin. A revised key to the eleven phyllophorine (Family Phyllophoridae, Subfamily Phyllophorinae) species now known from China is presented.
\end{abstract}

Key words: Phyllophorus (Phyllophorus) maculatus, Yellow Sea, Holothuroidea, Dendrochirotida

\section{Introduction}

Since the publication of Liao and Pawson (2001) on the dendrochirote and dactylochirote sea cucumbers of China, further investigations in the collections of the Institute of Oceanology, Chinese Academy of Sciences (IOCAS), have revealed ten specimens of a new phyllophorid species from the Yellow Sea. This new species brings to 36 the number of phyllophorids now known from China.

\section{Order Dendrochirotida}

\section{Family Phyllophoridae Östergren, 1907}

The family Phyllophoridae is well represented in China by 36 species.

\section{Subfamily Phyllophorinae Heding \& Panning, 1954}

Including the new species described here, eleven species of phyllophorines are now known from China. Two new species were described by Liao and Pawson (2001).

The relevant section of the key to holothurians of China, provided by Liao (1997), is revised and presented below.

\section{Key to members of the subfamily Phyllophorinae known from China}

1. Tentacles 30 . Anthochirus loui Chang, 1948

- Tentacles 20

2. Ossicles four-pillared tables with high spires, the pillars connected by three or more transverse bridges................... 3

- Ossicles four-pillared tables with low spires, one transverse bridge present, or bridges absent .................................7

3. Tentacles 20 in a single ring................................... Phyllophorus (Isophyllophorus) orientalis Liao \& Pawson, 2001

- Tentacles 20 in two rings. 
4. Spires of tables exceedingly high, with about ten transverse bridges

Phyllophorus (Phyllothuria) hypsipyrga (Marenzeller, 1881)

- Spire of table moderately high, with 3-6 transverse bridges

5. Spire of table topped with numerous closely crowded spines

.. Phyllophorus (Phyllothuria) cebuensis (Semper, 1868)

- Spire of table topped with few spines, not closely crowded.

6. Ossicles in tube feet similar to those in body wall.

.Phyllophorus (Phyllothuria) ordinatus Chang, 1935

- Ossicles in tube feet irregular tables with discs divided into two to five lobes

Phyllophorus (Phyllothuria) donghaiensis Liao \& Pawson, 2001

7. Ossicles absent from body wall except near posterior end; tables with nodulous periphery......

Phyllophorus (Phyllophorus) maculatus new species

- Ossicles common in all parts of body wall; tables with or without nodulous periphery

8. Calcareous ring with long posterior projections, each composed of about 8-12 pieces.

- Calcareous ring with relatively short posterior projections, each composed of five or fewer pieces

9. Discs of tables with peripheral knobs; body fusiform, up to $50 \mathrm{~mm}$ long

. Phyllophorus (Phyllophorella) dubius (Cherbonnier, 1960).

- Discs of tables without peripheral knobs; body vermiform, up to $200 \mathrm{~mm}$ long ...

.. Phyllophorus (Phyllophorella) liuwutiensis Yang, 1937

10. Tables irregular, discs with marginal projections. Phyllophorus (Phyllophorella) spiculata Chang, 1935

- Tables regular, discs lacking marginal projections Phyllophorus (Phyllophorella) kohkutiensis Heding \& Panning, 1954

\section{Genus Phyllophorus Grube, 1840}

\section{Subgenus Phyllophorus (Phyllophorus) Grube, 1840}

The subgenus Phyllophorus (Phyllophorus) currently comprises three species - the type species $P$. (P.) urna Grube, 1840 (see Heding \& Panning, 1954), from the Mediterranean; P. (P.) pedinaequalis Cherbonnier, 1969, from off NW Spain; and $P$. (P.) roseus Cherbonnier and Feral, 1976, from Indonesia.

\section{Phyllophorus (Phyllophorus) maculatus, new species}

Figures 1-2

Diagnosis: Medium-sized, up to $80 \mathrm{~mm}$ long and $20 \mathrm{~mm}$ in diameter. Body cylindrical, posterior end more or less tapering. Tube feet small, scattered on body wall, more numerous ventrally. Tentacles 20 in three circles, $10+5+5$. Calcareous ring with medium-length posterior projections on radials, each composed of about 10 small pieces. Ossicles in form of four-pillared tables with low spires, scarce in body wall, present only in posterior region near anus.
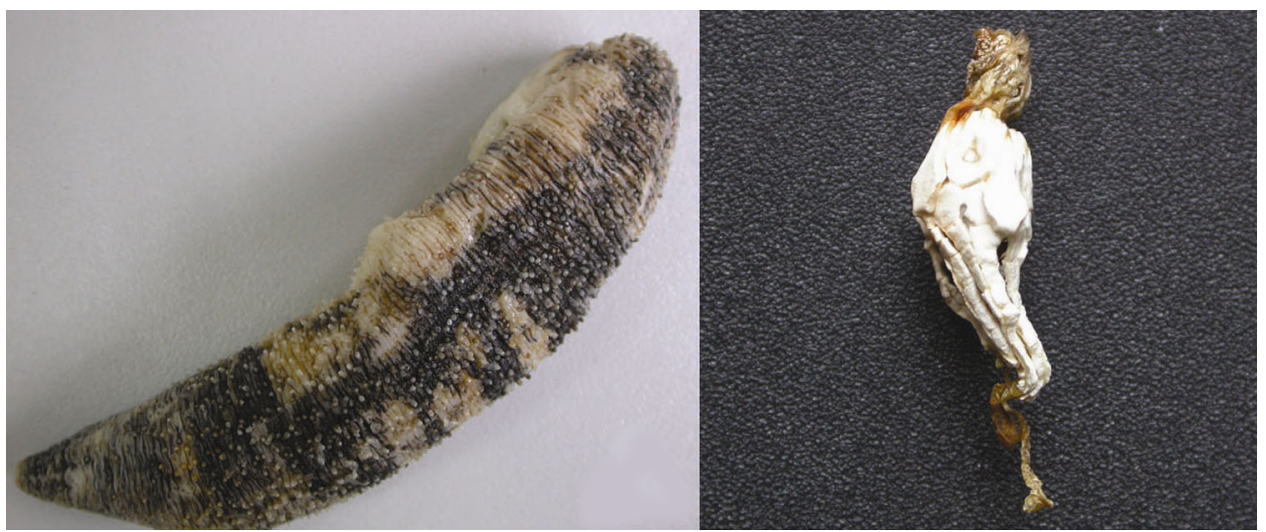

FIGURE 1. Phyllophorus (Phyllophorus) maculatus new species. Left, lateral view of Holotype, total length $80 \mathrm{~mm}$. Right, calcareous ring of a Paratype, length of ring $20 \mathrm{~mm}$. 
Material Examined: HOLOTYPE, IOCAS E-1110, Yellow Sea, $36^{\circ} \mathrm{N}, 120^{\circ} \mathrm{E}, 16$ September 2002, $32 \mathrm{~m}$, muddy sand bottom. PARATYPES IOCAS E-1111, Yellow Sea, 36º N, 120 30' E, 19 October 2000, $30 \mathrm{~m}, 2$ specimens; IOCAS E-1112, Yellow Sea, 35³ 30'N, 121³0'E, 19 May 2001, 32 m, 1 specimen; IOCAS E-

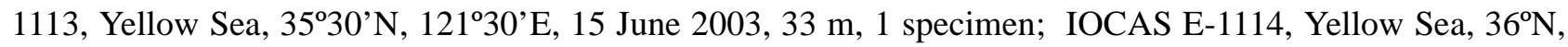
$121^{\circ} \mathrm{E}, 15$ June 2004, $32 \mathrm{~m}, 1$ specimen; IOCAS E-1115, Yellow Sea, 35 30’ N, $121^{\circ} \mathrm{E}, 15$ June 2003, $35 \mathrm{~m}$,

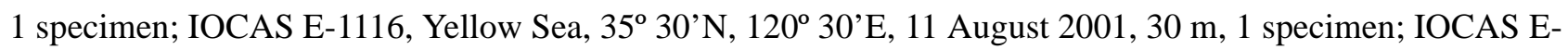
1117, Yellow Sea, $36^{\circ} \mathrm{N}, 121^{\circ} \mathrm{E}, 15$ June 2003, $22 \mathrm{~m}, 1$ specimen; IOCAS E-1118, Yellow Sea, 3530'N, 121³0'E, 19 May 2001, 45 m, 1 specimen. All specimens collected with a Petersen grab.

Description: Holotype (Figure 1) $80 \mathrm{~mm}$ long, diameter at mid-body $20 \mathrm{~mm}$. Body cylindrical, slightly curved, with anterior end rounded, posterior end more or less tapering. Tentacles retracted; anus terminal, surrounded by five minute papillae. Tentacles 20 , apparently in three circles of $10+5+5$. Tube feet small, numerous, scattered all over body, more numerous ventrally than dorsally. Body wall thick, soft. Color in alcohol whitish or cream, with numerous black bands or patches.

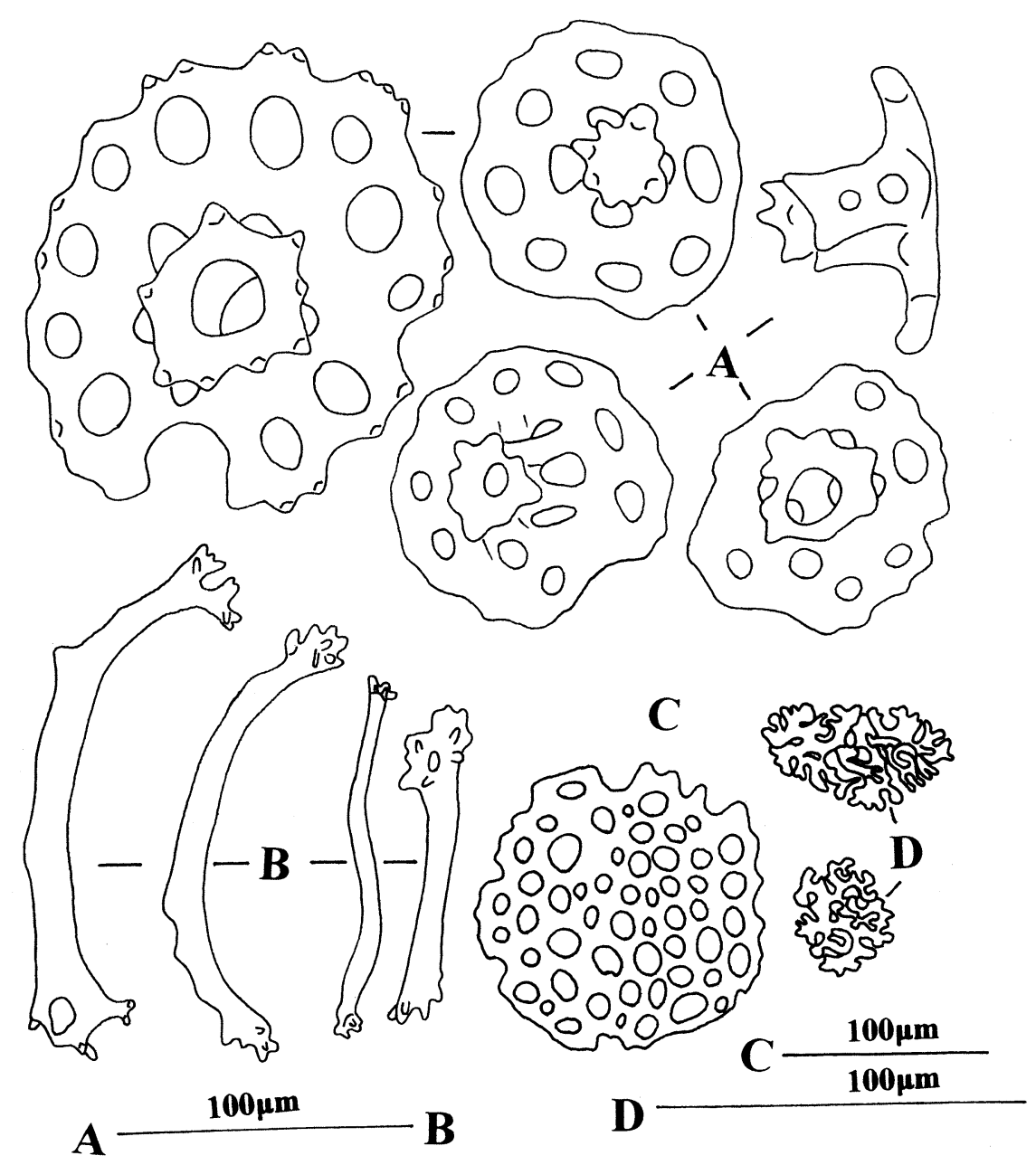

FIGURE 2. Phyllophorus (Phyllophorus) maculatus new species. A, tables from posterior end of body; B, rods from tentacles; $\mathrm{C}$, endplate from tube foot; $\mathrm{D}$, rosettes from introvert.

Ossicles in body wall scarce or absent. No ossicles in anterior and middle part of body, except for endplates in tube feet (Figure 1C). Ossicles present only in vicinity of anus, as tables (Figure 2A) with low fourpillared spires. Disk perforated by four large central holes and 8-12 small peripheral holes; edge of disc sinuous, with small peripheral knobs. Spire end in crown of eight spines. Disk diameter $74-179 \mu \mathrm{m}$ (average

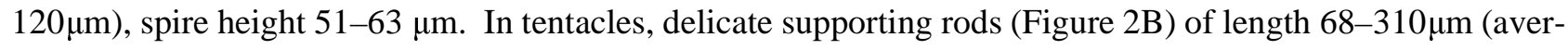
age $180 \mu \mathrm{m}$ ), often with one or two perforations at extremities. In introvert, rosettes only (Figure 2D). 
Paratypes: Nine paratypes collected near or at same station as holotype. Two paratypes lack ossicles altogether; collectors noted that these two specimens had been placed in formalin for several days; presumably ossicles dissolved due to acidic conditions. In one paratype tube feet arranged in five double rows in radii, and apparently absent from interradii; other features identical with those of the holotype. Calcareous ring (Figure 1) large, about $20 \mathrm{~mm}$ in length, including posterior projections, ring composed of five compound radial and five single interradial plates. Radials divided anteriorly into two unequal halves by a deep notch; posterior projections each composed of 8-10 small pieces. Interradials lower, more or less triangular, anterior point attenuate, posterior base broad, rounded. Polian vesicle and stone canal single.

Etymology: The species name is derived from Latin macula, in reference to the blotches of color on the body wall of this species.

Remarks: It is assumed that this is a burrowing species, like most of its relatives. This new species differs from its consubgeners in possessing body wall tables with short spires, the tables present only in the vicinity of the anus; in the shape of the calcareous ring; and in the color of the body.

\section{Acknowledgements}

We are grateful to Mr. Wang Hongfa and Mr. Chang Baolin for collecting the specimens. We thank Mr. Shaoqing Wang, Mr. Yongqiang Wang, Miss Lianmei Shuai and Miss Shiling Li for generous assistance in sorting samples.

\section{References}

Chang, F.Y. (1935) Additions to the holothurians of the Chinese coast. Contributions from the Institute of Zoology, National Academy of Peiping, 2(3), 1-18.

Chang, F.Y. (1948) Echinoderms of Tsingtao. Contributions from the Institute of Zoology, National Academy of Peiping, 4, 33-104.

Cherbonnier, G. (1960) Holothuries recoltées par A. Gallardo dans la Baie de Nha-Trang (Sud Viet-Nam). Bulletin du Muséum National d'Histoire Naturelle, $2^{e}$ Série 32(5), 425-435.

Cherbonnier, G. (1969) Echinodermes récoltés par la Thalassa au large des côtes ouest de Bretagne et du Golfe de Gascogne. Bulletin du Museum National d'Histoire Naturelle $2^{e}$ Serie 41(1), 343-361.

Cherbonnier, G. \& Feral, J.P. (1976) Echinodermes: Holothuries. Resultats des Campagnes Musorstom, 1 (17), 357412.

Grube, A.E. (1840) Aktinien, Echinodermen und Würmer des Adriatischen und Mittelmeeres. Pages 33-43. Königsberg.

Heding, S.G. \& Panning, A. (1954) Phyllophoridae. Eine Bearbeitung der polytentaculaten dendrochiroten Holothurien der zoologischen Museum in Kopenhagen. Spolia Zoologica Musei Hauniensis, 13, 1-209.

Liao, Y. (1997) Fauna Sinica. Phylum Echinodermata. Class Holothuroidea. Science press, Beijing, 334 pp.

Liao, Y. \& Pawson, D.L. (2001) Dendrochirote and dactylochirote sea cucumbers (Echinodermata: Holothuroidea) of China, with descriptions of eight new species. Proceedings of the Biological Society of Washington, 114(1), 58-90.

Marenzeller, E. (1881) Neue Holothurien von Japan und China. Verhandlingar der Zoologisch-Botanischen Gesellschaft in Österreich, 31, 121-140.

Östergren, H. (1907) Zur Phylogenie und Systematik der Seewalzen. In: Tullberg, T. Zoologiska Studien, Almquist \& Wiksells, Uppsala, pp. 191-215.

Semper, C. (1868) Holothurien. Riesen im Archipel der Philippinen 2. Wissenschaftliche Resultate. Wilhelm Engelmann, Leipzig, pp. 1-288.

Yang, P.F. (1937) Report on the holothurians from the Fukien coast. Amoy Marine Biological Bulletin, 2(1-2), 1-46. 